\title{
Comparison of proprietary elemental and whole-protein diets in unconscious patients with head injury
}

\author{
D C JONES, A J RICH, P D WRIGHT, I D A JOHNSTON
}

\section{Summary and conclusions}

Forty men who had sustained head injury were randomly assigned to one of five groups to receive $0.2 \mathrm{~g}$ nitrogen $/ \mathrm{kg}$ body weight/day as either an elemental or a wholeprotein diet. Three proprietary elemental and two whole-protein diets were compared. The mean daily nitrogen intake was below $0.2 \mathrm{~g} / \mathrm{kg}$ in all groups, and was significantly lower in the groups receiving elemental compared with whole-protein diets. Energy intake was significantly different only between one group receiving an elemental and one receiving a whole-protein diet. Mean daily urinary nitrogen excretion was significantly lower in the groups receiving elemental diets, and mean daily nitrogen balance was negative in all groups except one receiving a whole-protein diet.

Reduced nitrogen intakes occurred particularly with the elemental diets, which often provoked reflex vomiting or gastric stasis. The need to introduce diets at reduced strength made a negative balance almost inevitable, but nutritional balance seemed to be more readily achieved with the whole-protein diets. More work is needed to assess the relative merits of these proprietary diets compared with tube feeds prepared in hospitals.

\section{Introduction}

Interest is increasing in the use of proprietary liquid diets either to supplement the food intake of undernourished patients or to provide total nutrition as a tube feed in patients unable to swallow normally. Liquid diets vary in composition but fall
Amino-acids were initially thought to be well absorbed, but evidence now indicates that they are perhaps not absorbed as readily as peptides or whole protein $s^{1}$ and may not stimulate protein synthesis as effectively as normal food. ${ }^{2}$ No clinical comparisons of the different liquid diets, however, are available. Are all the products equally as effective in maintaining nitrogen balance, and does the formulation affect amino-acid absorption, osmotically induced diarrhoea, and patient tolerance? It is important that clinical comparisons should be carried out in patients with a normal small intestine before studies are made on a more heterogeneous group with varying degrees of intestinal insufficiency.

We carried out a study in which the total nutritional requirements of patients unconscious after head injury were provided by various commercial elemental and whole-protein diets given via nasogastric tube.

\section{Methods}

Forty men who had sustained head injury were assigned randomly to one of five groups to be fed $0.2 \mathrm{~g}$ nitrogen $/ \mathrm{kg}$ body weight/day as either an elemental diet (Vivonex, Flexical, or Albumaid plus Caloreen) or a whole-protein diet (Clinifeed or Triosorbon). Energy intakes varied between groups, depending on the formulation of the diet. The ratio of nitrogen to energy was higher in the elemental diets, being provided chiefly as glucose. Albumaid did not contain an energy source, so a glucose polymer, Caloreen, was used to provide a nitrogen:energy ratio similar to that of the other elemental diets (table I).

Feeding began as soon as possible after admission, the feeds being one-third strength on day 1 and two-thirds strength on days 2 and 3 to reduce the effects of hypertonicity. Full-strength feeds were given

TABLE I-Composition and costs of diets used. (Figures calculated for an intake of $0 \cdot 2 \mathrm{~g}$ nitrogen $/ \mathrm{kg}$ for a man weighing $60 \mathrm{~kg}$ )

\begin{tabular}{|c|c|c|c|c|c|c|}
\hline & & $\begin{array}{l}\text { Vivonex } \\
\text { Standard }\end{array}$ & Flexical & $\begin{array}{c}\text { Albumaid } \\
\text { plus } \\
\text { Caloreen }\end{array}$ & $\begin{array}{c}\text { Clinifeed } \\
400\end{array}$ & $\begin{array}{l}\text { Triosorbon } \\
\text { MCT }\end{array}$ \\
\hline 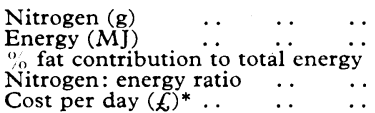 & $\begin{array}{l}\ldots \\
\cdots \\
\cdots\end{array}$ & $\begin{array}{c}12 \\
14 \cdot 6 \\
1 \cdot 3 \\
1: 1 \cdot 22 \\
6 \cdot 60\end{array}$ & $\begin{array}{c}12 \\
14 \cdot 0 \\
30 \cdot 5 \\
1: 1 \cdot 17 \\
7 \cdot 20\end{array}$ & $\begin{array}{c}12 \\
13 \cdot 9 \\
14 \cdot 0 \\
1: 1 \cdot 16 \\
3 \cdot 10\end{array}$ & $\begin{array}{c}12 \\
8 \cdot 4 \\
30 \cdot 0 \\
1: 0 \cdot 70 \\
3 \cdot 66\end{array}$ & $\begin{array}{c}12 \\
7 \cdot 7 \\
36 \cdot 3 \\
1: 0 \cdot 64 \\
2 \cdot 81\end{array}$ \\
\hline
\end{tabular}

*Based on hospital pharmacy costings at July 1979.
Conversion: SI to traditional units-Energy: $4 \cdot 18 \mathrm{MJ}=1000 \mathrm{kcal}$.

easily into two groups. In one, the so-called "elemental" diet, nitrogen is provided as essential amino-acids sometimes with oligopeptides. In the other, the nitrogen is in the form of whole protein usually derived from animal sources. Elemental diets are more costly than whole-protein diets, but both types may give rise to diarrhoea, particularly in the inflamed gut. This has usually been ascribed to high osmolality of the fluid feed, and whole-protein diets tend to correspond more closely to plasma osmolality.

\footnotetext{
Department of Surgery, Royal Victoria Infirmary, Newcastle upon Tyne NE1 4LP

D C JONES, MPHIL, SRN, research fellow

A J RICH, FRCs, lecturer (present appointment: research fellow, Medical College of Virginia, MCV Station, Richmond, Virginia 23298, USA)

P D WRIGHT, MD, FRCS, senior lecturer

I D A JOHNSTON, MCH, FRCS, professor
}

on days 4-12. The diet was given through a wide-bore nasogastric tube, either by bolus or by continuous drip. No other oral or intravenous nutrition was given.

Weight, triceps skinfold thickness, and arm muscle circumference were measured by standard techniques ${ }^{3}$ by the same observer before and after the study. Twenty-four-hour urine collections were made throughout the study, and urinary nitrogen was estimated on paired samples from each day's collection by using Kjeldahl's method. ${ }^{4}$ Each patient was assessed by using the injury severity score,${ }^{5}$ which gives a numerical value for the injuries sustained.

The results were analysed with Student's $t$ tests for paired and unpaired data as appropriate.

\section{Results}

The patients in each group did not differ significantly in terms of mean age, mean injury severity score, or nutritional state (table II). Mean weight, arm muscle circumference, and triceps skinfold 
thickness fell in all groups during the study. None of these reductions reached significance, and there were no significant differences between the groups.

Table III shows the mean daily intakes of nitrogen and energy for each group. In all groups the mean daily nitrogen intake was less than $0.2 \mathrm{~g} / \mathrm{kg}$, and the intakes in the groups receiving elemental diets (Vivonex Standard, Flexical, and Albumaid plus Caloreen) were significantly lower than those in the groups receiving wholeprotein diets (Clinifeed and Triosorbon). Energy intake was significantly higher in the group receiving Albumaid plus Caloreen compared $\mathrm{kcal}$ ) and $13 \mathrm{~g}$ of nitrogen to meet his nutritional needs. The average intake achieved, however, was $6.69 \mathrm{MJ}(1600 \mathrm{kcal})$ and $7 \mathrm{~g}$ nitrogen, and these low intakes would not be expected to maintain body cell mass. The differences in nitrogen excretion, however, cannot be explained entirely on the basis of differences in nitrogen intake, nor on the protein-sparing properties of carbohydrate in starvation.

The patients who received Clinifeed had the largest mean nitrogen intake and hence might be expected to have had the

TABLE II-Details of patients in each group before and after study period (results expressed as means $\pm S D$ )

\begin{tabular}{|c|c|c|c|c|c|c|}
\hline & & $\begin{array}{l}\text { Vivonex } \\
\text { Standard }\end{array}$ & Flexical & $\begin{array}{l}\text { Albumaid } \\
\text { plus } \\
\text { Caloreen }\end{array}$ & $\begin{array}{c}\text { Clinifeed } \\
400\end{array}$ & $\begin{array}{l}\text { Triosorbon } \\
\text { MCT }\end{array}$ \\
\hline \multicolumn{7}{|c|}{ Day 1} \\
\hline $\begin{array}{lll}\text { Median age (years) } & \ldots & \ldots \\
\text { Mean injury score } & \ldots & \ldots \\
\text { Mean weight }(\mathrm{kg}) & \ddot{ } & . \\
\text { Mean arm muscle circumference }(\mathrm{cm}) \\
\text { Mean triceps skinfold thickness }(\mathrm{mm})\end{array}$ & $\begin{array}{l}\cdots \\
\because \\
\therefore\end{array}$ & $\begin{array}{l}37 \\
32 \cdot 4 \pm 9 \cdot 3 \\
61 \cdot 6 \pm 4 \cdot 3 \\
23 \cdot 9 \pm 3 \cdot 0 \\
17 \cdot 1 \pm 10 \cdot 0\end{array}$ & $\begin{array}{l}\quad 42 \\
32 \cdot 1 \pm 7 \cdot 9 \\
61 \cdot 7 \pm 3 \cdot 4 \\
24 \cdot 8 \pm 2 \cdot 56 \\
17 \cdot 6 \pm 8 \cdot 8\end{array}$ & $\begin{array}{l}43 \\
30 \cdot 5 \pm 6 \cdot 1 \\
64 \cdot 5 \pm 2 \cdot 9 \\
23 \cdot 2 \pm 2 \cdot 9 \\
19 \cdot 2 \pm 6 \cdot 5\end{array}$ & $\begin{array}{l}38 \\
29 \cdot 7 \pm 6 \cdot 0 \\
63 \cdot 2 \pm 5 \cdot 1 \\
22 \cdot 3 \pm 3 \cdot 3 \\
21 \cdot 7 \pm 8 \cdot 4\end{array}$ & $\begin{array}{l}58 \\
33 \cdot 0 \pm 8 \cdot 6 \\
61 \cdot 2 \pm 7 \cdot 1 \\
23 \cdot 0 \pm 2 \cdot 9 \\
15 \cdot 3 \pm 6 \cdot 5\end{array}$ \\
\hline \multicolumn{7}{|c|}{ Day 12} \\
\hline $\begin{array}{l}\text { Mean weight }(\mathrm{kg}) \\
\text { Mean arm muscle circumference }(\mathrm{cm}) \\
\text { Mean triceps skinfold thickness }(\mathrm{mm})\end{array}$ & 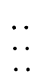 & $\begin{array}{l}58 \cdot 5 \pm 3 \cdot 3 \\
23 \cdot 9 \pm 2 \cdot 6 \\
15 \cdot 0 \pm 8 \cdot 4\end{array}$ & $\begin{array}{l}59 \cdot 0 \pm 3 \cdot 9 \\
24 \cdot 2 \pm 3 \cdot 3 \\
15 \cdot 1 \pm 8 \cdot 4\end{array}$ & $\begin{array}{l}61 \cdot 3 \pm 3 \cdot 1 \\
23 \cdot 2 \pm 3 \cdot 6 \\
16 \cdot 2 \pm 4 \cdot 5\end{array}$ & $\begin{array}{l}61 \cdot 5 \pm 5 \cdot 0 \\
22 \cdot 6 \pm 2 \cdot 9 \\
18 \cdot 1 \pm 8 \cdot 2\end{array}$ & $\begin{array}{l}58 \cdot 6 \pm 6 \cdot 1 \\
23 \cdot 0 \pm 3 \cdot 6 \\
13 \cdot 0 \pm 4 \cdot 9\end{array}$ \\
\hline
\end{tabular}

TABLE III-Mean $( \pm S D)$ daily energy intake and nitrogen balance for each feed, and significance of differences between feeds

\begin{tabular}{|c|c|c|c|c|c|c|c|}
\hline & & $\begin{array}{l}\text { Vivonex } \\
\text { Standard } \\
\text { (V) }\end{array}$ & $\begin{array}{c}\text { Flexical } \\
(\mathrm{F})\end{array}$ & $\begin{array}{c}\text { Albumaid plus } \\
\text { Caloreen } \\
\text { (AC) }\end{array}$ & $\begin{array}{l}\text { Clinifeed } 400 \\
\text { (C) }\end{array}$ & $\begin{array}{c}\text { Triosorbon } \\
\text { MCT } \\
(\mathrm{T})\end{array}$ & Significance \\
\hline Mean daily energy intake $(\mathrm{kJ} / \mathrm{kg}) \ldots$ & . & $104 \cdot 9 \pm 7 \cdot 5$ & $112 \cdot 9 \pm 15 \cdot 0$ & $126 \cdot 7 \pm 42 \cdot 2$ & $101 \cdot 6 \pm 18 \cdot 0$ & $86 \cdot 5 \pm 9 \cdot 2$ & $\mathrm{AC} v \mathrm{~T}: \mathrm{p}=0.034$ \\
\hline Mean daily nitrogen intake $(\mathrm{g} / \mathrm{kg})$ & $\cdots$ & $0.085 \pm 0.006$ & $0.099 \pm 0.013$ & $0.099 \pm 0.030$ & $0 \cdot 148 \pm 0.025$ & $0.135 \pm 0.015\{$ & $\begin{array}{l}\mathrm{C} v \mathrm{~V}, \mathrm{~F}, \mathrm{AC}: \mathrm{p} \leqslant 0.003 \\
\mathrm{~T} v \mathrm{~V}, \mathrm{~F}, \mathrm{AC}: \mathrm{p} \leqslant 0.009\end{array}$ \\
\hline $\begin{array}{l}\text { Mean daily urinary nitrogen excretion }(\mathrm{g} / \mathrm{kg}) \\
\text { Mean daily nitrogen balance }(\mathrm{g} / \mathrm{kg})\end{array}$ & $\cdots$ & $\begin{array}{r}0.161 \pm 0.009 \\
-0.080 \pm 0.014\end{array}$ & $\begin{array}{r}0.156 \pm 0.066 \\
-0.060 \pm 0.012\end{array}$ & $\begin{array}{r}0.144: 0.007 \\
-0.056 \div 0.009\end{array}$ & $\begin{array}{r}0.181 \pm 0.016 \\
-0.003 \pm 0.020\end{array}$ & $\begin{array}{l}0.131 \div 0.006 \\
0.005 \pm 0.018\end{array}$ & $\begin{array}{l}\mathrm{T} v \mathrm{~V}, \mathrm{~F}, \mathrm{C}: \mathrm{p} \leqslant 0.015 \\
\mathrm{~T} v \mathrm{~V}, \mathrm{~F}, \mathrm{AC}: \mathrm{p} \leqslant 0.01\end{array}$ \\
\hline
\end{tabular}

Conversion: SI to traditional units-Energy: $4 \cdot 18 \mathrm{~kJ}=1 \mathrm{kcal}$.

with the group receiving Triosorbon, but differences were otherwise not significant.

The mean daily urinary nitrogen excretion was significantly lower in the patients given Triosorbon than in those given Vivonex, Flexical, or Clinifeed, but was not significantly different from the value in the patients given Albumaid plus Caloreen. Mean daily nitrogen balance remained negative in all groups except that receiving Triosorbon: the balance in this group was significantly better than that found with Vivonex, Flexical, and Albumaid plus Caloreen.

\section{Discussion}

Although this study was designed to provide isonitrogenous diets for all groups, difficulties in using the elemental diets made it impossible to maintain the required intakes, as is evident from the appreciable differences in mean nitrogen intake. The elemental diets often provoked reflex vomiting or gastric stasis requiring a reduction in feed quantities or undue dilution, which inevitably led to reduced intakes of these diets. Diarrhoea, however, was not an important factor, as a similarly low incidence (two cases per 100 patient-days) was noted in all groups.

In addition to these differences in nitrogen intake energy intakes varied because of the differences in formulation of the diets, the ratios of nitrogen to energy in the whole-protein diets being considerably lower than those in the elemental diets. These two variables make interpretation of the results difficult. A typical patient in this study would require $8.36 \mathrm{MJ}(2000$ smallest nitrogen excretion, since obligatory protein breakdown and gluconeogenesis should have been more nearly balanced by this large intake. In fact the reverse occurred, and this group had the largest mean urinary nitrogen excretion.

The provision of carbohydrate after injury improves nitrogen retention, ${ }^{6}$ but if this was the sole explanation for the results the group with the greatest energy intake (patients receiving Albumaid plus Caloreen) might be expected to have had the lowest urinary nitrogen excretion. This, however, occurred in the group receiving Triosorbon, which had the lowest energy intake.

If nitrogen balance is indeed a guide to the clinical success of nutritional support in maintaining body cell mass, then these results suggest that whole-protein diets offer a distinct advantage over elemental diets. These improved balances, however, cannot be wholly attributed to differences in the source of dietary nitrogen. Further examination of the composition of the feeds showed that in the whole-protein diets (Clinifeed and Triosorbon) fat contributed much more to the total energy, and the proportion of nitrogen per $4 \cdot 18 \mathrm{MJ}(1000 \mathrm{kcal})$ was greater. Hence either the increased fat or nitrogen, or both, may have been responsible for the differences between the groups. Moreover, some of the superior properties of whole-protein diets may possibly be due to a lower osmolality and to better patient tolerance compared with elemental diets.

This study underlines the general difficulties that occur when an enteral diet is used in the face of catabolism. The need to introduce the diets at reduced strengths makes some degree of negative nutritional balance almost inevitable in the early 
period after injury and was certainly the reason for the tissue losses seen in this brief study.

Enteral diets used with an intact gut are a useful form of nutritional support, and nutritional balance seems to be more easily achieved with a whole-protein diet. Nevertheless, enteral diets used in the period after injury require as much attention to detail as parenteral feeding if maximum benefit is to be obtained. Proprietary enteral diets are expensive in comparison with tube feeds prepared in hospital diet kitchens. The relative merits of these diets compared with the proprietary products used in this study have yet to be examined.

We are grateful to the consultant staff of the Regional Neurosurgical Centre for permission to study their patients, and gratefully acknowledge the invaluable help of the nursing staff.

Requests for reprints should be sent to Mr P D Wright.

\section{References}

${ }^{1}$ Silk DBA. Physiology of protein absorption. Research and Clinical Forums 1979;1:29-34.

${ }^{2}$ Matthews DM, Payne JW. Nutrition of micro organisms and animals. In: Matthews DM, Payne JW, eds. Peptide transport and protein nutrition. Amsterdam: Associated Scientific Publishers, 1975:1-60.

${ }^{3}$ Jelliffe DB. Assessment of the nutritional state of the community. WHO Monograph 53. Geneva: World Health Organisation, 1966.

4 Varley H. Practical clinical biochemistry. 5th ed. London: Heinemann, 1967:193.

${ }^{5}$ Baker SP, O'Neill B, Haddon W, Long WB. The injury severity score: a method for describing patients with multiple injuries and evaluating emergency care. 7 Trauma 1974;14:187-96.

- Elwyn DH, Gump FE, Iles M, Long CL, Kinney JM. Protein and energy sparing of glucose added in hypocaloric amounts to peripheral infusions of amino acids. Metabolism 1978;27:325-31.

(Accepted 10 March 1980)

\title{
Staphylococcal bacteraemia, fusidic acid, and jaundice
}

\author{
M W HUMBLE, SUSANNAH J EYKYN, I PHILLIPS
}

\section{Summary and conclusions}

Fusidic acid was used to treat 131 out of 250 patients with staphylococcal bacteraemia over 10 years. Other antimicrobial agents were given to the 119 remaining patients. Thirty-seven patients were already jaundiced before antibiotic treatment was started. Jaundice developed during treatment in 38 out of 112 patients given fusidic acid (34\%) and in two out of 101 patients given other antimicrobials. The incidence of jaundice was higher in patients given fusidic acid intravenously $(48 \%)$ rather than by mouth $(13 \%)$. Jaundice appeared within 48 hours after the administration of fusidic acid in $93 \%$ of these cases. When the drug was stopped serum bilirubin concentrations fell to normal values within four days in those patients in whom they had been previously normal and who survived the bacteraemic episode. Fusidic acid was associated with increasing jaundice in 13 of 19 patients $(68 \%)$ already jaundiced before it was given. In six out of 32 patients who developed jaundice while receiving intravenous fusidic acid serum alkaline phosphatase activity was raised suggestive of cholestatic jaundice. The mechanism in the remaining patients was unknown.

Fusidic acid, particularly the intravenous preparation, is invaluable in treating severe staphylococcal infection but should be used with caution in patients with abnormal liver function. Patients receiving intravenous fusidic acid should be given the oral form of the drug as soon as their clinical condition permits.

\section{Introduction}

Fusidic acid is effective in vitro against Staphylococcus aureus and in treating severe staphylococcal infection. ${ }^{1-4}$ Populations of most staphylococci sensitive to fusidic acid, however, contain

\footnotetext{
Department of Microbiology, St Thomas's Hospital Medical School, London SE1 7EH

$M W$ HUMBLE, MRCPATH, lecturer (present appointment: consultant microbiologist, Wellington Hospital, New Zealand)

SUSANNAH J EYKYN, MRCPATH, senior lecturer

I PHILLIPS, MD, MRCPATH, professor
}

a few resistant organisms, ${ }^{5}$ and fully resistant populations emerge rapidly after exposure to the drug both in vitro ${ }^{5}$ and in vivo $^{6}$; hence it is usually given in combination with another antimicrobial. ${ }^{6}$

In recent reviews of drug jaundice ${ }^{7}$ and drug-induced liver disease $^{8}$ fusidic acid was not mentioned. Ernst ${ }^{9}$ reported increased activities of serum aspartate transaminase and serum alanine transferase in four of 73 patients with chronic staphylococcal osteitis and osteomyelitis treated with fusidic acid, and one of these four developed persistent ascites and chronic hepatitis. Menday and March, ${ }^{10}$ in a review of 46 patients treated with intravenous fusidic acid for severe staphylococcal infection, reported on two who became progressively jaundiced during treatment. One was already jaundiced before the drug was given, and in the other, who developed overwhelming staphylococcal pneumonia after influenza, the jaundice was attributed to the toxaemic process of the disease. Copperman $^{11}$ treated three patients with intravenous fusidic acid for severe staphylococcal infection: one had jaundice before the drug was given, but this disappeared during treatment. A further case of jaundice possibly associated with fusidic acid was reported by Craig ${ }^{12}$ in a patient with acute pustular psoriasis, who was also given clindamycin. The jaundice occurred three days after the antibiotics were started, and the bilirubin concentration fell two days after they were stopped.

Because of a clinical impression that fusidic acid, especially the intravenous preparation, might be associated with jaundice, we investigated cases of staphylococcal bacteraemia seen at this hospital during the past 10 years.

\section{Patients and methods}

From October 1969 the medical staff of the microbiology department kept prospective records of all patients with bacteraemia Aspects that might have predisposed to jaundice were recorded, including pre-existing liver or biliary tract disease, concomitant administration of potentially hepatotoxic drugs, and recent major operations. Monitoring liver function tests in staphylococcal bacteraemia was not part of the prospective study, and we did not attempt to influence these investigations when the patient was in hospital, since we were not initially aware of any association between fusidic acid and jaundice. The liver function tests were thus performed when clinically indicated and analysed retrospectively. 